\title{
Temperature Dependence of Activation and Inhibition of Mushroom Tyrosinase by Ethyl Xanthate
}

\author{
M. Alijanianzadeh and A. A. Saboury \\ Institute of Biochemistry and Biophysics, Eniversity of Tehran, Tehran, Iran. ${ }^{*}$ E-mail sabourvaut ac ir \\ Received December 21, 2006
}

\begin{abstract}
A new alkyldithiocarbonate (xanthate), as sodium salts. $\mathrm{C}_{2} \mathrm{H}_{5} \mathrm{OCS} \mathrm{S}_{2} \mathrm{Na}$. was synthesized by the reaction between $\mathrm{CS}_{2}$ with ethyl alcohol in the presence of $\mathrm{NaOH}$. The new xanthate was characterized by ${ }^{1} \mathrm{H} N \mathrm{NR}$. IR and elemental analysis. Then. the new synthesized compound was examined for functional study of cresolase activity of Mushroom Tỵrosinase (MT) from a commercial source of Agricus bisporus in $10 \mathrm{mM}$ phosphate buffer $\mathrm{pH} 6.8$. at three temperatures of 10.20 and $33^{\circ} \mathrm{C}$ using UV spectrophotemetry. 4-[(4-methylphenyl)azo]-phenol (MePAPh) was used as a synthetic substrate for the enzyme for cresolase reaction. The results show that ethyl xanthate can activate or inhibit the cresolase activity of mushroom ty rosinase depending to the concentration of ethyl xanthate. It was concluded that the enzyme has two distinct sites for ethyl xanthate. The first one is a high-affinity activation site and the other is a low-affinity inhibition site. Activation of the enzyme in the low concentration of ethyl xanthate arises from increasing the affinity of binding for the substrate as well as increasing the enzy'me catalytic constant. The affinity of ligand binding in the activation site is decreased by increasing of the temperature. which is the opposite result for the inhibition site. Hence, the nature of the interaction of ethyl xanthate is different in two distinct sites. The binding process for cresolase inhibition is only entropy driven. meanwhile the binding process for cresolase activation is not only entropy driven but also enthalpy' driven means that hỵdrophobic interaction is more important in the inhibition site.
\end{abstract}

Key Words : Mushroom ty rosinase. Ethỵl xanthate. Uncompetitive inhibition. Activation

\section{Introduction}

Tyrosinase (Monophenol mono-oxygenase: polyphenol oxidase: catechol oxidase: and oxygen oxidoreductase: EC. 1.14.18.1) is of central importance in vertebrate melanin pigmentation. ' Enzymatic browning in vegetables and fruits is caused by the activity of tyrosinase in plant tissues. Tỵrosinase playss an important role in fruit and vegetable processing and during the storage of processed foods. ${ }^{\text {. This }}$ enzyme catalyzes the hydroxylation of monophenols (monophenolase activity) and the oxidation of $o$-quinones evolved nonenzymatically to yield several unstable intermediates. which polymerize to render melanins. ${ }^{3}$ The active site of tyrosinase consists of two copper atoms and three states: "met' "deoxy", and "oxy" . 11 In some vegetables and fruits. tyrosinase is responsible for browning and is considered deleterious to the color quality of plant-derived foods and beverages. The unfavorable browning of raw fruits. vegetables and beverages is a major problem in the food industry and is believed to be one of the main causes of quality loss during post harvest handling and processing. ${ }^{12}$ Recently, the development of tyrosinase inhibitors has become an active alternative approach to control insect pests. ${ }^{13}$ In addition. it is well-recognized that tyrosinase inhibitors are important for their potential applications in medical and cosmetic products that may be used to prevent or treat pigmentation disorders. $^{1+16}$ Tyrosinase inhibitors may result in a reduction in melanin biosynthesis and are used in cosmetic products for perpigmentation-related concerns including the formation of freckles. ${ }^{17}$ Tyrosinase has three domains. of which the central domain contains two copper binding sites. Six histidine residues bind a pair of copper ions in the active site of tyrosinase. which interact with both molecular oxygen and its phenolic substrate. ${ }^{18}$ There is a vast variety of natural and synthetic inhibitors known against catecholase. cresolase or both reactions of tyrosinase. Polyphenols. aldehydes and their derivatives are the most important inhibitors from plant natural sources. ${ }^{19-22}$ Besides higher plants. some compounds from fungal sources have also been identified. e.g. metallothionein from Aspergillus niger. has strong avidity to chelate copper at the active site of MT. thereby acting as a strong inhibitor. ${ }^{23}$ Kojic acid. an antibiotic. produced by species of Aspergilhus and Penicillum in the aerobic process acts as a potent. "slow-binding", competitive inhibitor of ty rosinase. ${ }^{2+28}$ and is widely used as a cosmetic whitening agent ${ }^{28-31}$ Synthetic tyrosinase inhibitors may be used as drug and chemicals. In the case of clinical drugs. captopril an antihypertensive drug, and methimazole act as tyrosinase inhibitors. ${ }^{32.33}$ Sulfur-containing compounds such as tiron. thiol and sulfites are among the most important tyrosinase inhibitors. The most commonly applied inhibitor of the discoloration process currently is sulfite. ${ }^{3+}$ To understand the mechanism of enzyme action and inhibition. we have attempted to obtain additional information about the structure. function and relationship of musluroom tyrosinase (MT) ${ }^{35-39}$ After introducing two new bi-pyridine șynthetic compounds as potent uncompetitive MT inhibitors. ${ }^{4 !}$ the inhibitory effects of three synthetic $n$-alkyl dithiocarbamates with different tails. were elucidated. ${ }^{4 l}$ Understanding the role of hydrophobic and electrostatic interactions of inhibitor 
binding to the active site of the enzyme can lead to design new potent inhibitors for MT. Hence. in the present investigation. the effect of ethyl xanthate, sodium salt as a new synthesized conpound. on the cresolase activity of MT is described.

\section{Materials and Methods}

Materials. Mushroom tyrosinase (MT; EC 1.14.18.1). specific activity 3400 units $/ \mathrm{mlg}$, was purchased from Signa. 4-[(4-methylphenyl)azo]-phenol (MePAPh) as synthetic substrate for the enzyme for cresolase reaction (Figure la). was prepared as already explained. ${ }^{42}$ Ethyl xanthate (Figure lb) was synthesized. Ethanol. carbon disulfide and sodium hydroxide were purchased from Merck Chemical Co. Germany and used as received. Infrared spectrum was obtained on Nicolet 5-DXB FT-IR spectrophotometer in the range of $4000-400 \mathrm{~cm}^{-1}$ in $\mathrm{KBr}$ pellets. Microchenical analysis of carbon and hydrogen for the compound was carried out on an elemental analysis of CHN Rapid Herause. ${ }^{1} \mathrm{H}$ NMR spectrum was recorded on a Brucker DRX-500 Avance spectrophotometer at $500 \mathrm{MHz}$ in $\mathrm{DMSO}^{-\mathrm{d}_{6}}$ using sodium3-trimethylpropionate as internal reference. 'H NMR data are expressed in part per million (ppm) and are reported as chemical shift position $(\delta \mathrm{H})$, multiplicity ( $\mathrm{s}=$ singlet, $\mathrm{d}=$ doublet, $\mathrm{t}=$ triplet, $\mathrm{q}=$ quartet, $\mathrm{m}=$ multiple) and assignment. Melting point was measured on a Unimelt capillary melting point apparatus and is reported uncorrected.

Phosphate buffer ( $10 \mathrm{mM}$. $\mathrm{pH} 6.8$ ) was used throughout this research and the corresponding salts were obtained from Merck. Experiments were carried out at 10.20 and $33^{\circ} \mathrm{C}$.

\section{Methods}

Synthesis of sodium ethyl xanthate: This compound was prepared by an improved procedure as compared to that of given in the literature. $.^{43}+\mathrm{g}(100 \mathrm{mmol}) \mathrm{NaOH}$ and $5.87 \mathrm{~mL}$ (100 numol) ethanol were mixed together in a $100 \mathrm{~mL}$ stoppered flask and stirred to get homogenous curdy<smiles>Cc1ccc(/N=N/c2ccc(O)c(O)c2)cc1</smiles>

(a)

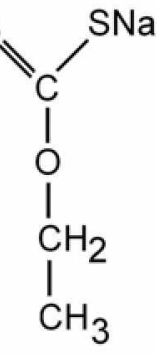

(b)

Figure 1. 4-[(4-methylphenyl)azo]-phenol (MePAPh) (a), as synthetic substrate for MT for cresolase reaction (figure la). Ethyl dithioxantate as new ligand (Figure lb). solution. The flask was kept in an ice bath and $20 \mathrm{~mL}$ of CS: (200 mumol) was added dropwise with constant stirring over a period of $30 \mathrm{~min}$, the solution became cloudy yellow. Then the mouth of reaction vessel was closed using a proper stopper and left to stir for $\mathrm{l} h$ in the ice bath and $2 \mathrm{~h}$ at room temperature. This crude product was completely dried at 35 ${ }^{\circ} \mathrm{C}$ and made powder in a mortar. This powder were stirred with $30 \mathrm{~mL}$ acetone over a period of $10 \mathrm{~min}$. and filtered in pump to remove undissolved particles. To the filterate 40 $\mathrm{mL}$ diethylether was added and kept in refrigerator overnight. The bright yellow crystals obtained were filtered and washed twice with ether and dried at $35^{\circ} \mathrm{C}$. (yield $11.52 \mathrm{~g}$. $80 \%$ and decomposes at $104{ }^{\circ} \mathrm{C}$ ). ${ }^{1} \mathrm{H}$ NMR $(500 \mathrm{MHz}$, DMSO-d $6 . p p m): 4.19$ (q. O-CH2). $1.15\left(\mathrm{t}, \mathrm{O}-\mathrm{CH}_{2} \mathrm{CH}_{3}\right.$ ). Analytical calculated for $\mathrm{C}_{4} \mathrm{H}_{7} \mathrm{OS}_{2} \mathrm{Na}: \mathrm{C} .25 .00: \mathrm{H} .3 .47$. Analytical found: C. $25.10:$ H. 3.43. Solid-state IR spectroscopy of sodium ethyl xanthate showed two characteristic bands at 1127 and $1035 \mathrm{~cm}^{-1}$ assigned to $v_{c-0}$ and $v_{c-s}$ modes, which are similar to the others reported. ${ }^{43.45}$

Kinetic measurements: Kinetic assay of cresolase activity was carried out tlurough depletion of MePAPh. for $2.5 \mathrm{~min}$. with enzyme concentration of $112.68 \mu \mathrm{g} / \mathrm{mL}$. at $352 \mathrm{~nm}$ wavelengths using a Cary spectrophotometer, 100 Biomodel, with jacketed cell holders. Freshly prepared enzyme, substrate. etlyyl xanthate were used in this work. All the enzymatic reactions were run in phosphate buffer $(10 \mathrm{mM})$ at $\mathrm{pHs} 6.8$ in a conventional quartz cell thermostated. Substrate addition followed after incubation of enzyme with different concentrations of ethyl santhate.

\section{Results and Discussion}

The effect of temperature on the binding processes of ethyl xanthate to mushroom tyrosinase in the cresolase activity was studied at three temperatures of 10.20 and 33

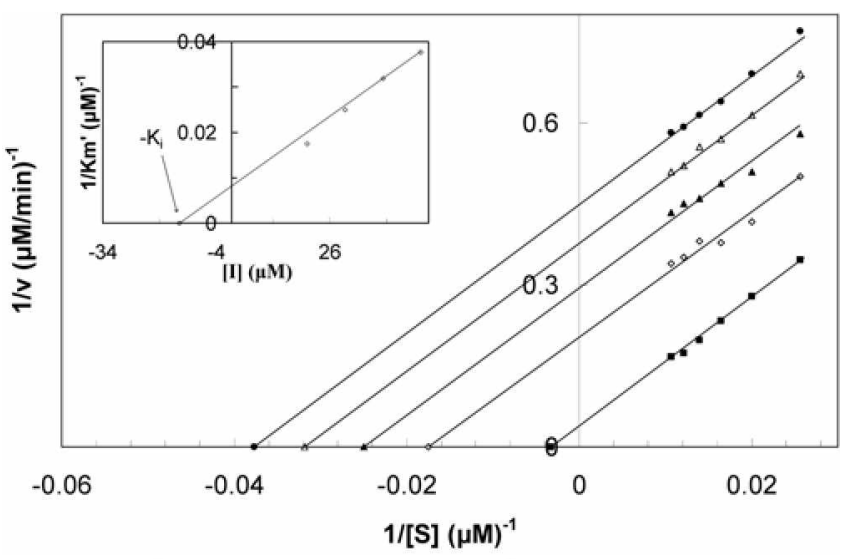

Figure 2. Double reciprocal Lineweaver-Burk plots of MT kinetic assays for cresolase reactions of MePAPh in $10 \mathrm{mM}$ phosphate buffer, $\mathrm{pH}=6.8$, at $20^{\circ} \mathrm{C}$ and $112.68 \mathrm{tg} / \mathrm{mL}$ enzyme concentration, in the presence of different fixed concentrations of ethyl xanthate: 0 $\iota \mathrm{M}(\mathbf{\square}), 20, t \mathrm{M}(\sqsupset), 30, t \mathrm{M}(\Delta), 40, t \mathrm{M}(\doteq), 50, t \mathrm{M}(\bullet)$. Insect: the secondary plot, the $1 / \mathrm{K}_{\mathrm{m}}$ against different concentrations of inhibitor, which gives the inhibition constant $\left(-\mathrm{K}_{1}\right)$ from the abscissa-intercepts. 


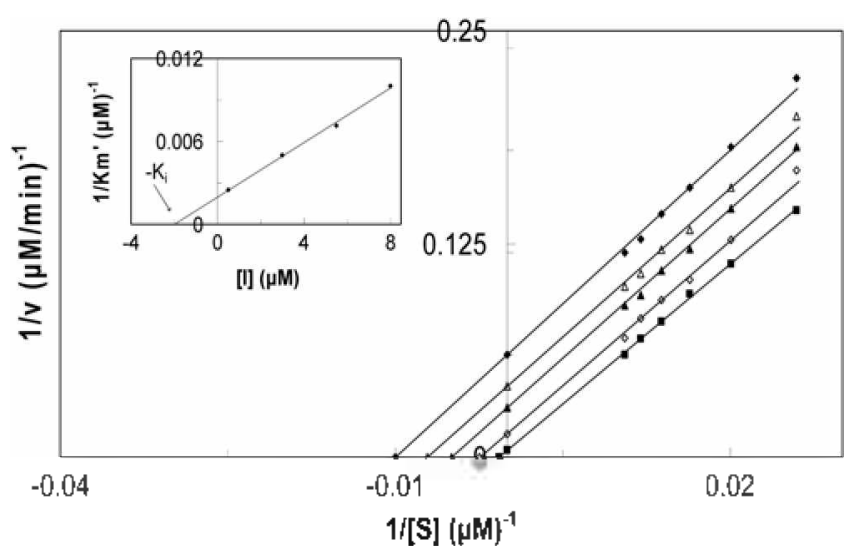

Figure 3. Double reciprocal Lineweaver-Burk plots of MT kinetic assays for cresolase reactions of MePAPh in $10 \mathrm{mM}$ phosphate buffer, $\mathrm{pH}=6.8$, at $33^{\circ} \mathrm{C}$ and $112.68 \mathrm{~kg} / \mathrm{mL}$ enzyme concentration, in the presence of different fixed concentrations of ethyl santhate: 0 $/ \mathbb{M}(\mathbf{\square}), 0.5(\sqsubset), 3, / \mathrm{M}(\Delta), 5.5, / \mathrm{M}(\therefore), 8, \mathbb{M}(\bullet)$. Insect: the secondary plot, the $1 / \mathrm{K}_{\mathrm{rl}}$ against different concentrations of inhibitor, which gives the inhibition constant $\left(-\mathrm{K}_{1}\right)$ from the abscissa-intercepts.

${ }^{\circ} \mathrm{C}$. Experiments were done in two ranges of relatively high $(20-50 \mu \mathrm{M})$ and low $(0.5-11.5 \mu \mathrm{M})$ concentrations of ethyl xanthate.

Kinetic parameters of inhibition of cresolase activity at two different temperatures of 20 and $33^{\circ} \mathrm{C}$. Double reciprocal Lineweaver-Burk plots for the cresolase activity of MT on hydroxylation of MePAPh. as the substrate, in the presence of relatively high different fixed concentrations of ethyl xanthate. $20-50 \mu \mathrm{M}$, at $20^{\circ} \mathrm{C}$ are shown in Figures 2 . The same plots. but in the presence of relatively low different fixed concentrations of ethyl xanthate, 0.5-8.0 $\mu \mathrm{M}$. at $33^{\circ} \mathrm{C}$ are shown in Figures 3. All Lineweaver-Burk plots show a set of parallel straight lines, which intersect the horizontal axis, (see Figures 2 and 3), which confirms uncompetitive inhibition at both temperatures. independent of the concentration range of inhibitor. The apparent maximum velocity ( $\mathrm{V}_{\text {max }}$ ) and apparent Michaelis constant $\left(K_{m}\right)$ values can be obtained at different fixed concentrations of inhibitor. ${ }^{46}$ A secondary plot of the $1 / K_{\mathrm{m}}$ ' against the concentration of inlubitor gives a straight line with an abscissa-intercept of $-K_{1}$. (see the insect of Figures 2 and 3 ). where $K_{1}$ is the inhibition constant. The $K_{t}$ values have been sunumarized in Table $\mathrm{I}$ indicating that the inhibition constant is smaller at $33^{\circ} \mathrm{C}$. means that the inhibitor has more affinity for binding to the enzyme at higher temperature.

Kinetic parameters of activation of cresolase activity at two different temperatures of 10 and $20^{\circ} \mathrm{C}$. Figures 4 and 5 show the double reciprocal Lineweaver-Burk plots for the cresolase activity of MT on hydroxỵlation of MePAPh in the presence of relatively low different concentrations of ethyl xanthate at $10^{\circ} \mathrm{C}$ and $20^{\circ} \mathrm{C}$. respectively. Both figures show a series of straight lines intersects each other on the left hand side of the vertical axis. over the horizontal axis. indicating activation of MT at relatively low concentrations of ethyl xanthate. The kinetic pathway of activation for ethyl xan-
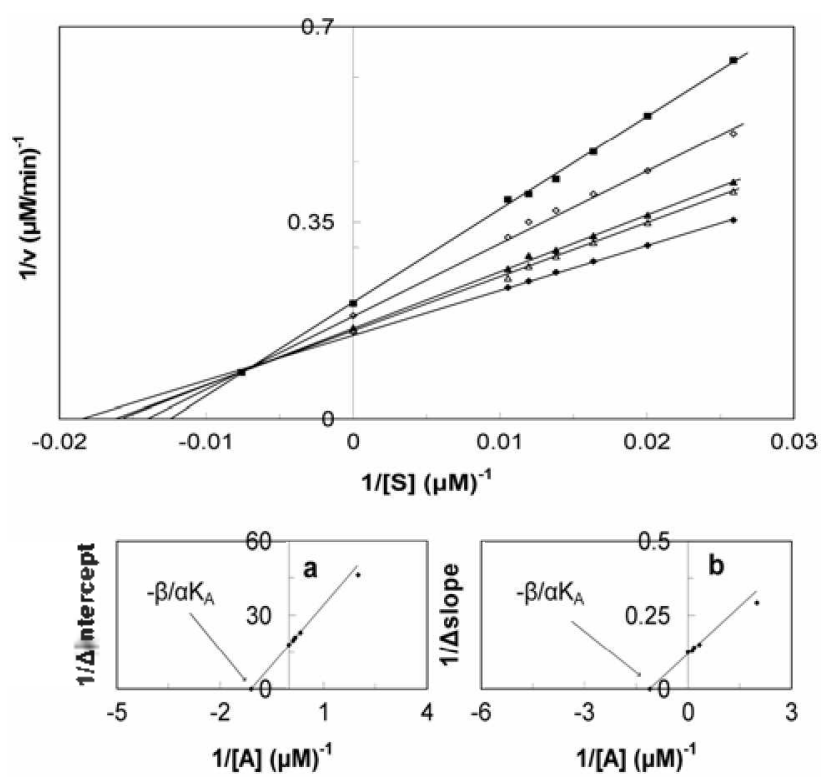

Figure 4. MT kinetic assays for cresolase reactions of MePAPh in $10 \mathrm{mM}$ phosphate bufter, $\mathrm{pH}=6.8$, at $11^{\circ} \mathrm{C}, 112.68 \mathrm{~kg} / \mathrm{mL}$ enzyme concentration, in the presence of difterent fived concentrations of ethyl wanthate: $8, t \mathrm{M}(\mathbf{\square}), 5.5, \mathrm{tM}(\sqsubset), 3, t \mathrm{M}(\backsim), 0.5, / \mathrm{M}(\therefore), 0.0$ $\mu \mathrm{M}(\bullet)(a)$. the secondary plot, the $1 / \Delta$ intercept against $1 /[\mathrm{A}]$, which gives $-f \alpha \alpha \mathrm{K}_{\mathrm{A}}$ from the abscissa-intercepts (b). the secondary plot, the $1 / \Delta$ slope against $1 /[\mathrm{A}]$, which gives $-f / \alpha \mathrm{K}_{\mathrm{A}}$ trom the abscissa-intercepts (c).
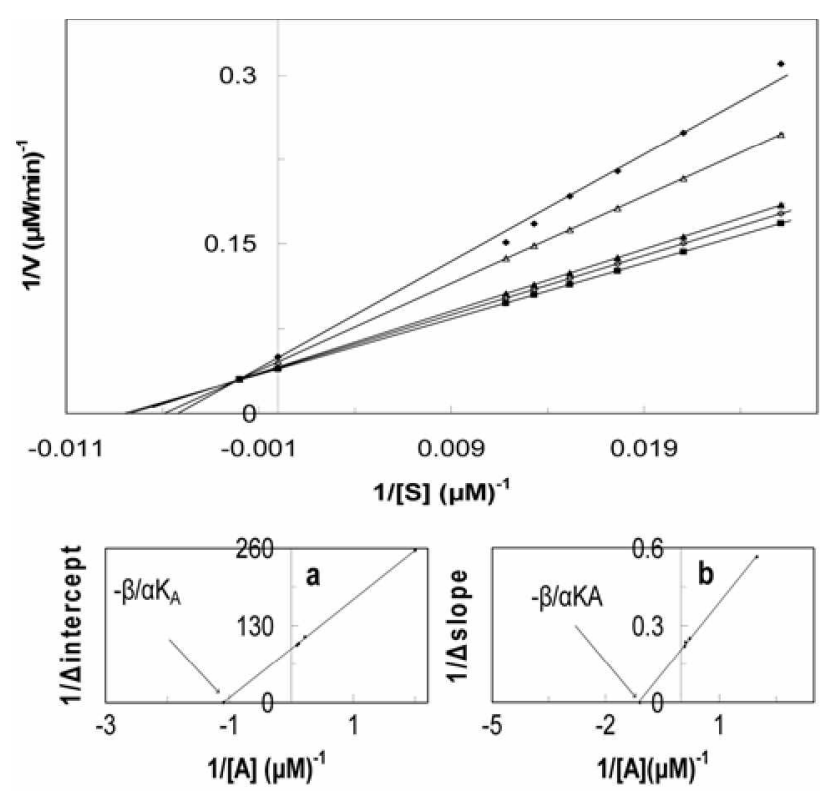

Figure 5. MT kinetic assays for cresolase reactions of MePAPh in $10 \mathrm{mM}$ phosphate buffer, $\mathrm{pH}=6.8$, at $20^{\circ} \mathrm{C}, 112.68 \mathrm{~kg} / \mathrm{mL}$ enzyme concentration, in the presence of different fixed concentrations of

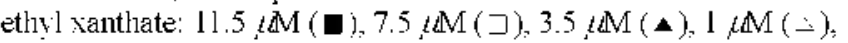
$0.0 \mathrm{MM}(\bullet)$ (a) the secondary plot, the $1 / \Delta$ intercept against $1 /[\mathrm{A}]$, which gives $-\beta a \mathrm{~K}_{\mathrm{A}}$ from the abscissa-intercepts (b). the secondary plot, the $1 / \Delta$ slope against $1 /[\mathrm{A}]$, which gives $-\beta / \alpha \mathrm{K}_{A}$ from the abscissa-intercepts (c).

thate follows the general non-essential activation system. The apparent maximum velocity $\left(\mathrm{V}_{\mathrm{max}}{ }^{\prime}\right)$ and apparent dis- 


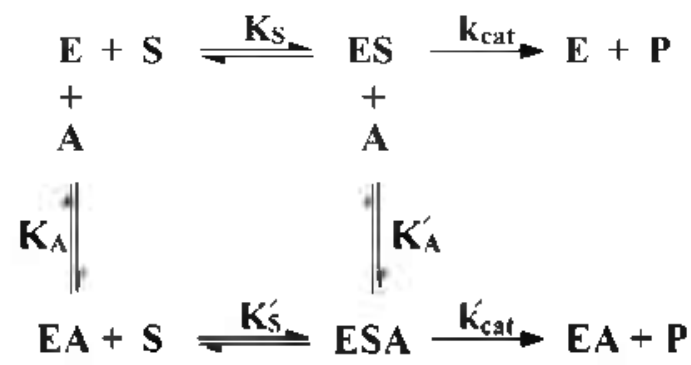

Scheme 1

sociation constant of the substrate. $\mathrm{S},\left(\mathrm{K}_{s^{\prime}}\right)$ values can be obtained at any fixed concentrations of ethyl xanthate from the vertical (Y) and abscissa (X) intercept, respectively. The rapid-equilibrium model has been proposed to describe the non-essential activation of an enzyne by an activator molecule A, Scheme $1 .^{+6}$ In this model, $\mathrm{V}_{\max }{ }^{\prime}=\mathrm{V}_{\max }(1+\beta[\mathrm{A}]$ $\left.\alpha \mathrm{K}_{\mathrm{A}}\right) /\left(\mathrm{l}+[\mathrm{A}] / \alpha \mathrm{K}_{\mathrm{A}}\right)$ and $\mathrm{K}_{\mathrm{S}^{\prime}}=\mathrm{K}_{\mathrm{S}}\left(\mathrm{l}+[\mathrm{A}] / \alpha \mathrm{K}_{\mathrm{A}}\right) /(\mathrm{l}+[\mathrm{A}] /$ $\left.\alpha \mathrm{K}_{\mathrm{A}}\right) . \mathrm{K}_{\mathrm{s}}$ is the dissociation constant of the substrate from the enzyme. $K_{A}$ is the dissociation constant of the effector from the enzyme. $\alpha$ and $\beta$ represent maximal changes in $\mathrm{K}_{\mathrm{s}}$ and $V_{\text {max }}$ of the enzyme in the presence of ethyl xanthate. respectively. and $[\mathrm{A}]$ is the concentration of ethyl xanthate as the activator. $V_{\text {max }}$ and $\mathrm{K}_{\mathrm{S}}$ values are obtained from the $\mathrm{Y}$ intercept and $\mathrm{X}$-intercept of the Linweaver-Burk linear plot. respectively. in the absence of the activator. Then. the slope and Y-intercept changes in the Linweaver-Burk plot due to the presence of ethyl xanthate at different concentration are obtained and replotted their inverse versus inverse concentration of the activator as the secondary plots to find $\alpha \beta$ and $K_{A}$ values. The linear plot of $1 / \Delta$ Slope against $1 / \Delta A$ shows the Y-intercept of $\beta \mathrm{V}_{\text {max }} /(\beta-\mathrm{l})$ and the $\mathrm{X}$-intercept of $-\beta / \alpha \mathrm{K}_{A}$. The linear plot of $1 / \Delta \mathrm{Y}$-intercept against $1 / \Delta \mathrm{A}$ shows the Y-intercept of $\beta \mathrm{V}_{\text {лаa }} / \mathrm{K}_{\mathrm{s}}(\beta-\alpha)$ and the $\mathrm{X}$-intercept of $-\beta\left(\alpha \mathrm{K}_{\mathrm{A}} . \alpha, \beta\right.$ and $\mathrm{K}_{\mathrm{A}}$ values have been summarized in Table 2 . The $\alpha$ values $(\alpha<1)$ obtained herein suggest that the binding of ethyl xanthate to the enzyme can increase the binding affinity of the substrate. The $\beta$ values $(\beta>1)$ obtained also suggest that the binding of ethyl xanthate to the enzyme can increase the maximum velocity of the enzyme due to the increase of the enzyme catalytic constant $(h$ cat $)$. Hence. ethyl xanthate activates the enzyme not only by increasing the affunity of binding of the substrate for MT but also by increasing the enzyme catalytic constant.

By increasing the temperature to $33^{\circ} \mathrm{C}$. the activation of MT was not observed in low concentration of ethyl xanthate (data are not showed) because the binding affinity for inhibition process is increased.

In order to understand the effect of temperature on the
Table 1. Themodynamic parameters of binding ethyl xanthate, as an inhibitor, on cresolase activity of mushroom tyrosinase at two different temperatures at pH 6.8

\begin{tabular}{cccccc}
\hline $\begin{array}{c}\mathrm{T} \\
\left({ }^{\circ} \mathrm{C}\right)\end{array}$ & $\begin{array}{c}\mathrm{K}_{\mathrm{a}} \\
(\mathrm{M})^{-1}\end{array}$ & $\begin{array}{c}\mathrm{K}_{1} \\
(t / \mathrm{M})\end{array}$ & $\begin{array}{c}\Delta \mathrm{G}^{\circ} \\
(\mathrm{kJ} / \mathrm{mol})\end{array}$ & $\begin{array}{c}\mathrm{T} \Delta S^{\circ} \\
(\mathrm{k} \mathrm{K} / \mathrm{mol})\end{array}$ & $\begin{array}{c}\Delta \mathrm{H}^{\circ} \\
(\mathrm{kJ} / \mathrm{mol})\end{array}$ \\
\hline 20 & $7.2 \times 10^{4}$ & 13.8 & -27.25 & 13838 & 111.13 \\
33 & $5.0 \times 10^{\circ}$ & 2.0 & -33.38 & 12425 & \\
\hline
\end{tabular}

inhibition and to shed light into the nature of the ethyl santhate binding with MT, the change of the standard Gibbs free energy of binding $\left(\Delta \mathrm{G}^{\circ}\right)$ was calculated using the association binding constant $(\mathrm{K})$, obtained from the inverse of $\mathrm{K}_{1}$ value, in the equation $(1)^{47}$.

$$
\Delta \mathrm{G}^{\mathrm{o}}=-\mathrm{R} \mathrm{T} \ln \mathrm{K}
$$

Where $\mathrm{R}$ is the gas constant, and $\mathrm{T}$ is the absolute temperature. The standard enthalpy change of binding $\left(\Delta \mathrm{H}^{\dagger}\right)$ was also calculated using $\mathrm{K}$ values at two temperatures in van't Hoff equation ${ }^{47}$ :

$$
\ln \mathrm{K}_{2} / \mathrm{K}_{1}=-\Delta \mathrm{H}^{\circ} / \mathrm{R}\left(1 / \mathrm{T}_{2}-1 / \mathrm{T}_{1}\right)
$$

Where $\mathrm{K}_{1}$ and $\mathrm{K}_{2}$ are association binding constants at two temperatures of $T_{1}$ and $T_{2}$, respectively. Finally the standard entropy changes $\left(\Delta S^{\circ}\right)$ were calculated using the equation (3). ${ }^{47}$

$$
\Delta \mathrm{S}^{\circ}=\left(\Delta \mathrm{H}^{\circ}-\Delta \mathrm{G}^{\circ}\right) / \mathrm{T}
$$

All calculated themodynamic parameters $\left(\mathrm{K} . \Delta \mathrm{G}^{\circ} . \Delta \mathrm{H}^{\circ}\right.$ and $\Delta S^{\circ}$ ) for two inlubition and activation binding sites are summarized in Tables 1 and 2, respectively. The results show that the binding process for both inhibition and activation are spontaneous at both temperature $\left(\Delta \mathrm{G}^{\circ}<0\right)$. Besides. the binding process of ethyl xanthate seems to be only entropy driven $\left(\Delta S^{\circ}>0\right)$ in the inhibition; however, the binding process for the activation is not only entropy driven but also enthalpy driven.

We have reported $n$-alkyl dithiocarbamates as potent synthetic inhibitors due to $\mathrm{K}_{1}$ values of $0.8,1.0$ and $1.8 \mu \mathrm{M}$ in cresolase activity for $n$-butyl dithiocarbamate, $n$-hexyl dithiocarbamate and $n$-octyl dithiocarbamate. sodium salts.

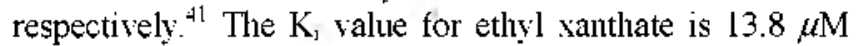
means that $n$-alkyl dithiocarbanates are more potent inhibitors than ethyl xanthate. However. ethỵl xanthate can activate MT in low concentrations.

As a conclution, there are two distinct sites for the binding of ethyl xanthate to MT, one for activation with high affinity and the other for inhibition with low affinity. The hydrophobic interaction is more important in the inhibition site

\begin{tabular}{|c|c|c|c|c|c|c|c|c|c|}
\hline $\begin{array}{c}\mathrm{T} \\
\left({ }^{\circ} \mathrm{C}\right)\end{array}$ & $\alpha$ & $\beta$ & $\begin{array}{c}\mathrm{K}_{\mathrm{d}} \\
(\mathrm{M})^{-1}\end{array}$ & $\begin{array}{c}\mathrm{K}_{\mathrm{H}} \\
(t \mathrm{M})\end{array}$ & $\begin{array}{c}\mathrm{K}_{\mathrm{S}} \\
(\epsilon \mathrm{M})\end{array}$ & $\begin{array}{c}\mathrm{V}_{\text {trax }} \\
(\mathrm{M} / \mathrm{M} / \mathrm{min})\end{array}$ & $\begin{array}{c}\Delta \mathrm{G}^{\circ} \\
(\mathrm{kJ} / \mathrm{mol})\end{array}$ & $\begin{array}{c}\mathrm{T} \Delta \mathrm{S}^{\circ} \\
(\mathrm{k} \cdot \mathrm{T} / \mathrm{mol})\end{array}$ & $\begin{array}{c}\Delta \mathrm{H}^{\circ} \\
(\mathrm{k} \mathrm{k} / \mathrm{mol})\end{array}$ \\
\hline 10 & 0.71 & 1.37 & $5.9 \times 10^{5}$ & 1.7 & 80.64 & 4.82 & -31.26 & 23.87 & \multirow{2}{*}{-739} \\
\hline 20 & 0.62 & 1.28 & $5.3 \times 10^{5}$ & 1.9 & 191.66 & 20.23 & -32.11 & 24.72 & \\
\hline
\end{tabular}

Table 2. Themody namic parameters of binding ethyl santhate, as an activator, on cresolase activity of mushroom tyrosinase at two different temperatures at $\mathrm{pH} 6.8$ 
than to the activation site due to the binding process for inhibition is only entropy driven. The activation of the enzyme by ethyl xanthate is related to the increase of the binding affuity for substrate $(\alpha<1)$ as well as the increase of the enzyme catalytic constant $(\beta>1)$. The inhibition process overcomes to the activation process in $33^{\circ} \mathrm{C}$ due to the increase of binding affinity for inhibition site. Hence, the activation of MT is occurred at low concentration of ethyl vanthate at low temperatures.

Acknowledgements. The fulancial support given by the University of Teluran and the Iran National Science Foundation (INSF) are gratefully acknowledged.

\section{References}

1. Espin. J. C.: Varon. R.: Fenoll. L. G.: Gilbert. M. A.: Garcia-Ruiz. P. A.: Tudela. J.: Garcia-Vanovas. F. Ezt: J. Biochent. 2000. 267. 1270 .

2. Robb, D. A. In Copper Protems and Copper Enzmes. Lontie, R. Ed.: CRC Press: Boca Raton. 1984: Vol. 2. pp 207-240.

3. Prota. G. In Melonins and helanogenesis. Jovanovich. H. B., Ed.: Academic Press: San Diego. 1992: pp 34-62.

4. Mason. H. S. Nuture 1956. 177.79.

5. Jolly: R. L. Jr; Evans, L. H.: Mason. H. S. Biochem. Bioplys. Res. Conmmin. 1972, +6.878

6. Schoot-Uiterk. J.: Mason. H. S. Proc. Natl. Acad Sci. LS. 1973. 70.993 .

7. Jolly. R. L. Jr:: Evans. L. H.: Makino. N.: Mason. H. S. J. Biol. Chem. 1974. 249.335

8. Makino, N.: Mason. H. S. J. Biol. Chem 1973, 2ł8. 5731.

9. Makino, N.: MeMalill, P.: Mason, H. S.: Moss, T. H. J. Biol. Chem 1974, 249.6062.

10. Schoot-Uiterkamp. A. J. M.: Evans. L. H.: Jolley. R. L.: Mason. H. S. Biochim. Biophws. Acta 1976. 453.200

11. Lerch. K. In Afetal Ions in Biologicat Sistents: Sigel. H. Ed.: Marcel Dekker Inc.: New York. 1981: pp 143-186.

12. Chen, Q.X.: Lilı. X.-D.: Huang. H. Biochemistry Aloscow 2003. 68,644

13. Yu. L. Agric. Food Chem. 2003. 51.2344

14. Pawelek. J. M.: Korner. A. M. Am. Sci. 1982. 70.136.

15. Maeda. K.: Fukuda. M. J. Soc. Cosmet Chem 1991. 12. 361

16. Mosher. D. B.; Pathak. M. A.: Fitzpatric, T. B. In Lpdate: Dermatology in General Medicine: MeGraw Hill: New York: 1983: pp 205-225.

17. Whitaker. J. R. In Food Enzintes. Structure and Mechanisms: Wong. D. W. S.. Ed.: Chapman and Hall: New York. 1995: pp $271-307$.

18. Jackman M. P.: Hajnal. A.: Lerch. K. Biochem. J. 1991. 274.707.

19. Kubo, I, Kinst-Hori, I. J. Agric. Food Chem. 1999, 47. 4121.
20. Kubo. I.: Kinst-Hori. I.: Ishiguro. K.: Chaudhuri. S. K.: Sanchez. Y: Ogura. T. Bioong. Med. Chent. Lett. 1994. t. 1443

21. Kubo. I.: Kinst-Hori. I.: Chaudhuri. S. K.: Kubo. Y.: Sanchez. Y. Ogura. T. Bioorg. 1 led. Chem. 2000, 8. 1749.

22. Kubo, I.: Kinst-Hori. I. J. Agric. Food Chem 1988, 46, 5338

23. Goetghebeur. M.: Kermasha. S. Phochemisny 1996, +2.935.

24. Kim. Y. M.: Yun. J.: Lee. C. K.: Lee. H.: Min. K. R.: Kimn. Y. J. Biol. Chem. 2002. 227. 16340.

25. Chen. J. S.: Wei. C.: Rolle. R. S.: Otwell. W. S.: Balban. M. O Marshall, M. R. J.Agric. Food Chem. 1991, 39. 1396.

26. Chen. J. S.; Wei. C.: Marshall. M. R. J. Agic. Chem. 1991, 39. 1897.

27. Kaht1. V. In Enzmatic Broming and Its Prevention: Lee. C. Y. Whitaker. I. R.. Eds.: American Chemical Society: Washington DC. 1995: pp 277-294

28. Kahn. V: Ben-Shalom. N.: Zakin, V. J. Agric. Food Chem. 1997. 45. 4460 .

29. Cabanes. J.: Chazarra, S.: Garcia-Carmona, F. J. Pham. Phamacol. $1994+6.982$

30. Lim. I. T. Derntatol. Sing. 1999. 25. 282

31. Battaini. G.: Motzani. E.: Casella. L.: Santagostini. L.: Pagliarit1. R. J. Biol horg Chem 2000, 5, 262

32. Espin, J. C.: Wichers, H. G. Biochem. Biophus, Acta 2001. 1554. 289.

33. Andrawis. A.: Khan1. V. Biochem. J. 1996. 235.91

34. Taylor. S. L.: Bush. R. K. Food Techmol 1986. +0. 47

35. Haghbeen. K.: Saboury. A. A.: Karbassi. F. Biochint Biophns. Acta 2004. 1675. 139

36. Karbassi, F.: Haghtreen, K: Saboury. A. A.: Ranjbar. B. Moosavi-Movahedi, A. A. Coll. Suf. B: Bionterfaces 2003. 32 137.

37. Shareeti-Borojerdi. S.: Haghbeen. K.: Karkhane. A. A.: Fazli. M.: Saboury. A. A. Biochent. Biophns. Res. Commum 2004. 314. 925.

38. Gheibi, N.: Saboury. A. A.: Haghbeen, K: Moosavi-Movahedi. A. A. Coll. Surf. B: Biointerfaces 2005. $45,104$.

39. Karbassi, F.: Haghtheen, K: Saboury. A. A.: Ranjbar. B. Moosavi-Movahedi. A. A.: Falzami. B. Iht J. Biol. Mfacronol. 2004. 34. 257.

40. Karbassi. F.: Saboury. A. A.: Hassant-Khant. M. T:: IqualChoudhar, M: Saifi. Z. S. J. Enz. Inhib. Hed. Chem. 2004. 19. 349 .

41. Gheibi, N.: Saboury, A. A.: Mansury-Torshizy, H.: Haghbeen. K: Moosavi-movahedi. A. A. J. Enz. Inthb. Med Chem. 2004. 20. 393.

42. Haghbeen. K.: Tan1. E. W. J. Org. Chem. 1998. 63. 4503

43. Leskovac, V. Comprehensive Enzume Kinetics. Kluwer Academic Plenum Publisher: New York, 2003: Chapter 7, p 111

4. Ahmed. A. M.; Ibrahim, K.: Anna, O. R.: John, P. F.. Jr. Inorg Chent 2004. +3. 3833 .

45. Fackler. T. P. Ir: William. C. S. Inorg Chem. 1969.8. 1631 .

46. Katsoulos. G. A.: Tsipis. C. A Inorg Chim. Acta 1984. 8t. 89.

47. Atkins, P; DePaula, J. Phwsical Chemistrw, 7th ed: WH Freeman \& Company: New York. 2002: Chap 9 